\title{
Optimization of Alkaline Activator Mixing and Curing Conditions for a Fly Ash-Based Geopolymer Paste System
}

\author{
Omar A. Abdulkareem ${ }^{1} \&$ Mahyuddin Ramli ${ }^{1}$ \\ ${ }^{1}$ School of Housing, Building and Planning, Universiti Sains Malaysia (USM), Penang, Malaysia \\ Correspondence: Omar A. Abdulkareem, School of Housing, Building and Planning, Universiti Sains Malaysia \\ (USM), 11800 Penang, Malaysia. Tel: 60-184-075-047. Fax: 60-046-576-523. E-mail: \\ abdulkareem@usm.my/eng.omar83@yahoo.com
}

Received: June 3, 2015

Accepted: June 19, 2015

Online Published: October 31, 2015

doi:10.5539/mas.v9n12p61

URL: http://dx.doi.org/10.5539/mas.v9n12p61

\begin{abstract}
This article reports the strength development and microstructure characteristics of a fly ash (FA) geopolymer system prepared with an alkaline activator consisting of sodium hydroxide $(\mathrm{NaOH})$ solution and liquid sodium silicate $\left(\mathrm{Na}_{2} \mathrm{SiO}_{3}\right)$. The effect of $\mathrm{Na}_{2} \mathrm{SiO}_{3} / \mathrm{NaOH}$ mass mixing ratio on the compressive strength and microstructure characteristics of hardened FA geopolymers at different ages was investigated. The influence of different curing conditions on the strength development of the FA geopolymer was also explored. The experimental results revealed that the alkaline activator prepared with $\mathrm{Na}_{2} \mathrm{SiO}_{3} / \mathrm{NaOH}$ ratio of 1.00 provides sufficient alkalinity to promote the geopolymerization reaction and development of high-strength FA geopolymer material. The scanning electron microscopy (SEM) results showed that the dissolution rates of the FA extremely affected by the content of $\mathrm{NaOH}$ solution in the liquid activator. Also, the most effective curing regime was $70{ }^{\circ} \mathrm{C}$ for $24 \mathrm{~h}$ to produce geopolymers with optimal strength at different aging periods.
\end{abstract}

Keywords: geopolymer, alkaline activator, SEM, curing condition, curing temperature, compressive strength

\section{Introduction}

The production of ordinary Portland cement (OPC) is one of the industries that significantly contribute to carbon dioxide $\left(\mathrm{CO}_{2}\right)$ emission during the calcination process of the OPC prime material. Hardjito and Rangan (2005) reported that the production of 1 ton of OPC emits approximately 1 ton of $\mathrm{CO}_{2}$ to the atmosphere because of the calcination and fuel combustion, which mainly involves fossil fuel. The demand for new infrastructures and buildings has increased because of the continuous increase in the human population worldwide; thus, the construction technology is facing a huge environmental challenge of developing green construction materials (binders) in addition to OPC. The geopolymer material is a novel green construction material has been proposed to replace OPC. In comparison with OPC, geopolymer materials can reduce $\mathrm{CO}_{2}$ emission by $80 \%-90 \%$ (Davidovits, 1999) and exhibit better mechanical and durability properties (Li, Ding \& Zhang, 2004; Wallah \& Rangan, 2006; Gourley \& Johnson, 2005). The geopolymerization technology involves the alkaline activation of typical precursors to form an aluminosilicate gel structure through the polycondensation reaction at low temperatures; these precursors include metakaolin, fly ash (FA), slag, and rice husk ash, which contain abundant silica $\left(\mathrm{SiO}_{2}\right)$ and alumina $\left(\mathrm{Al}_{2} \mathrm{O}_{3}\right)$ (Duxson et al., 2007; Detphan \& Chindaprasirt, 2009) . In this technology, a green geopolymer binder (cement) prepared from waste materials like FA is more beneficial to the environment because it diminishes waste quantities disposed in landfills. FA geopolymer materials exhibit high mechanical properties, low density, low water absorption, negligible shrinkage, and high chemical and fire resistance (Thakur \& Ghosh, 2006). Given these properties, FA geopolymer materials are considered as an alternative to OPC particularly because they can reduce $\mathrm{CO}_{2}$ emissions by $80 \%$ compared with OPC (Hardjito \& Rangan, 2005). Previous studies reported that FA geopolymer concrete can achieve compressive strength higher than 60 MPa after thermal curing (Kovalchuk, Fernández-Jiménez \& Palomo, 2007; Duxson et al., 2005). This material also presents excellent durability to most aggressive acids (Fernández-Jiménez, Garcia-Lodeiro \& Palomo 2007) and can resist sulfate attacks better than OPC mortars in reinforcement steel (Wallah et al., 2005; Song et al., 2005; Fernandez-Jimenez, Palomo \& Lopez-Hombrados, 2006).

FA, a by-product of pulverized coal combustion in thermal power plants, is primarily composed of silicon $\left(\mathrm{SiO}_{2}\right)$, aluminum $\left(\mathrm{Al}_{2} \mathrm{O}_{3}\right)$, iron $\left(\mathrm{Fe}_{2} \mathrm{O}_{3}\right)$, and calcium $(\mathrm{CaO})$ oxides, with less amounts of magnesium, potassium, sodium, 
titanium, and sulfur oxides (Hardjito \& Rangan, 2005). Accordingly, a highly alkaline activator is required to dissolve the acidic oxides of FA; therefore the usage of normal water in the activation process of a FA source is inappropriate. The common alkaline activator used to prepare FA geopolymers is a liquid combination of sodium hydroxide $(\mathrm{NaOH})$ or potassium hydroxide $(\mathrm{KOH})$ and sodium silicate $\left(\mathrm{Na}_{2} \mathrm{SiO}_{3}\right)$ or potassium silicate $\left(\mathrm{K}_{2} \mathrm{SiO}_{3}\right)$ (Kong \& Sanjayan, 2008; Kong \& Sanjayan, 2008; Rukzon, Chindaprasirt \& Mahachai, 2009; Nazari, Riahi \& Bagheri, 2012). Many studies used Na-based activators to prepare FA geopolymers because of their economic advantages (Rashad, 2014; Temuujin, van Riessen \& MacKenzi, 2010; Nematollahi \& Sanjayan, 2014; Ryu et al., 2013). The content and concentration of liquid alkaline activator play a fundamental role in the development of high-strength FA geopolymers at low temperatures (Ryu et al., 2013); these factors also determine the thermal durability or fire resistance of FA geopolymers exposed to temperatures higher than $100{ }^{\circ} \mathrm{C}$ (Abdulkareem et al., 2013; Abdulkareem et al., 2014).

According to Glukhovsky, (1981), the mechanism of alkali-activation is composed of conjoined reactions of destruction-condensation, that include the destruction of the prime material like FA into low stable structural units, their interaction with coagulation structures and creation of condensation structures. The authors estimated that the first steps consisting of breakdown of covalent bounds of $\mathrm{Si}-\mathrm{O}-\mathrm{Si}$ and $\mathrm{Al}-\mathrm{O}-\mathrm{Si}$, which happened when the $\mathrm{pH}$ of the alkali solution rises, so those groups are transformed to a colloid phase. Then an accumulation of the destroyed products occurs, which interacts among them to form a coagulated structure, leading in a third phase to the generation of a condensed structure.

Alvarez-Ayuso et al., (2008) reported that the geopolymerization reaction occurs in the alkaline solutions with aluminosilicate oxides and silicates (either solid or liquid) as reactants. In addition, the mechanism involving the dissolution of the aluminum (Al) and silicon ( $\mathrm{Si}$ ) species from the surface of the source material as well as the surface hydration of undisclosed particles. Afterward, the polymerization of active surface groups and soluble species take place to form a gel, generating subsequently a hardened structure.

Thakur \& Ghosh, (2009) reported a description for the geopolymerization of FA geopolymers, as the main reaction product in the alkali-activated FA is an alkaline silico-aluminate gel and the $\mathrm{OH}^{-}$ions acts as a reaction catalyst during the activation process, while the alkaline metal $\left(\mathrm{Na}^{+}\right)$acts as a structure-forming element. The structure of the pre-zeolite gel chains $\mathrm{Si}$ and $\mathrm{Al}$ tetrahedral randomly distributed along the polymeric chains that are cross-linked so as to provide cavities of sufficient size to accommodate the charge balancing hydrated sodium ions (Xu \& Deventer, 2000). Furthermore, the development of the compressive strength of the hardened FA geopolymers is attributed to the resulted aluminosilicate gel phase in the geopolymer matrices.

This work aims to evaluate the effect of alkaline activator concentration on the strength development and microstructure of FA geopolymers. The geopolymers were prepared with the selected activator/FA ratio of 0.59 , various mixing ratios of the activator solution constituents, and different curing regimes. The prepared geopolymers were used to determine the role of activator constituents in the geopolymerization reaction and strength development of FA geopolymers.

\section{Experimental Procedure}

\subsection{Source Materials}

FA was provided by the Manjung Power Station, Lumut, Perak, Malaysia. FA was stored under shade at ambient temperature and covered by a thin plastic layer to protect from ambient humidity and maintain clean powder. FA was analyzed prior to mixing, and its chemical composition was determined using X-ray fluorescence (Table 1). FA contained high $\mathrm{Fe}_{2} \mathrm{O}_{3}(30.13 \%)$ and $21.6 \% \mathrm{CaO}$, and thus classified as class $\mathrm{C}$ according to ASTM C618 (2008). With a specific surface area of $0.463 \mathrm{~m}^{2} / \mathrm{g}$, about $90 \%$ of FA presented particle size smaller than $40 \mu \mathrm{m}$ as indicated in the particle size analysis results of Figure 1. Figure 2 presents the XRD diffractogram of the FA showing that the FA is mainly an amorphous material with the appearance of a typical broad hallow at 16 to 38 $2 \theta$. However, the FA diffractogram is also contains some of crystalline phases of quartz $\left(\mathrm{SiO}_{2}\right)$ at $21,26.6$ and 65 $2 \theta$, mullite $\left(3 \mathrm{Al}_{2} \mathrm{O}_{3} \cdot 2 \mathrm{SiO}_{2}\right)$ at 17.1 and $28.32 \theta$ and hematite $\left(\mathrm{Fe}_{2} \mathrm{O}_{3}\right)$ at 24,35 and $412 \theta$.

Table 1. Chemical composition of fly ash using XRF.

\begin{tabular}{lllllllllllll}
\hline Chemical & $\mathrm{SiO}_{2}$ & $\mathrm{Al}_{2} \mathrm{O}_{3}$ & $\mathrm{Fe}_{2} \mathrm{O}_{3}$ & $\mathrm{TiO}_{2}$ & $\mathrm{CaO}$ & $\mathrm{MnO}$ & $\mathrm{CuO}$ & $\mathrm{K}_{2} \mathrm{O}$ & $\mathrm{P}_{2} \mathrm{O}_{5}$ & $\mathrm{SO}_{3}$ & $\mathrm{SrO}$ & LOI* \\
\hline$\%$ & 26.4 & 9.25 & 30.13 & 3.07 & 21.6 & 0.27 & 0.14 & 2.58 & 0.67 & 1.3 & 1.57 & 3.02 \\
\hline
\end{tabular}

*LOI: loss on ignition. 


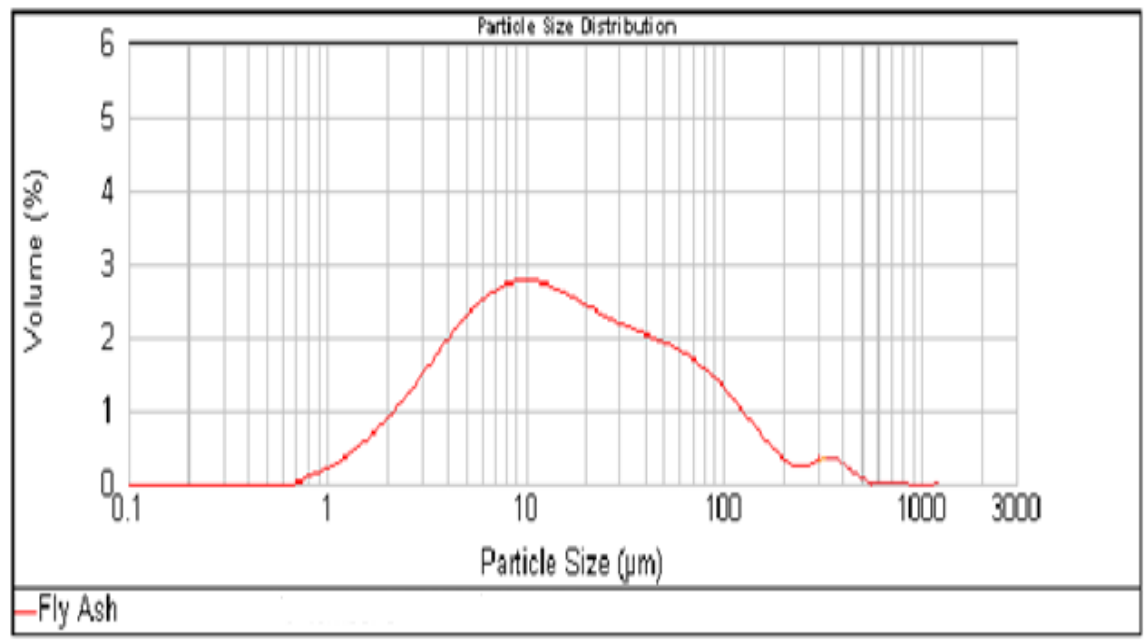

Figure 1. Particle size distribution of the FA

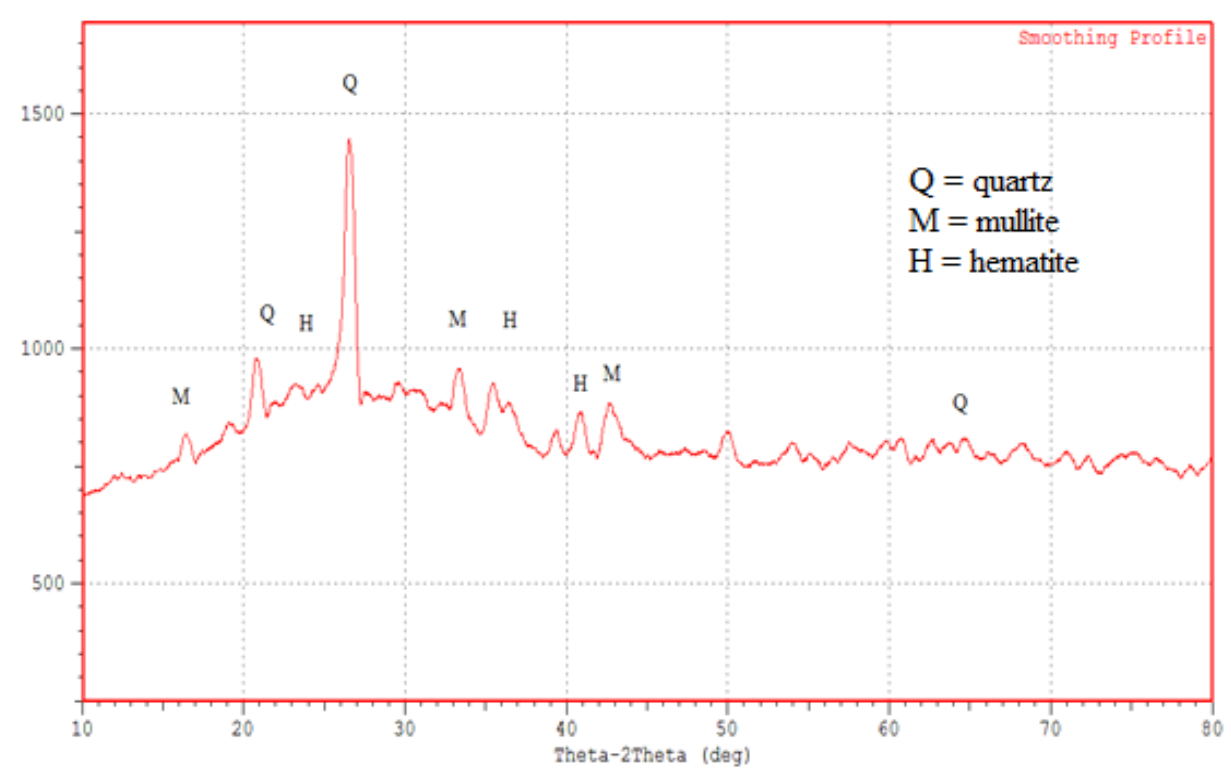

Figure 2. XRD diffraction pattern of the FA.

FA was activated with an alkaline activator, which was prepared by mixing technical-grade $\mathrm{Na}_{2} \mathrm{SiO}_{3}(\mathrm{Sigma}$ Chemical Ltd.) and $\mathrm{NaOH}$ solution. The chemical composition of $\mathrm{Na}_{2} \mathrm{SiO}_{3}$ was $30.1 \% \mathrm{SiO}_{2}, 9.4 \% \mathrm{Na}_{2} \mathrm{O}$, and $60.5 \% \mathrm{H}_{2} \mathrm{O}$, with a modulus ratio $\left(M_{S}\right)$ equal to $3.2\left(M_{S}=\mathrm{SiO}_{2} / \mathrm{Na}_{2} \mathrm{O}\right)$.

\subsection{Specimen Preparation}

\subsubsection{Preparation of FA geopolymer Paste with Different Mass Ratios of $\mathrm{Na}_{2} \mathrm{SiO}_{3} / \mathrm{NaOH}$}

An alkaline activator was prepared by mixing $12 \mathrm{M} \mathrm{NaOH}$ solution with $\mathrm{Na}_{2} \mathrm{SiO}_{3}$ at six $\mathrm{Na}_{2} \mathrm{SiO}_{3} / \mathrm{NaOH}$ mixing ratios ranging from 0.5 to 3.0 with 0.5 increment to investigate the effect of mass ratio on the strength development of FA geopolymer paste. The mixture proportions of geopolymer pastes are listed in Table 2 . Geopolymer paste specimens were synthesized by gradually adding the alkaline activator to dry FA at an activator/FA ratio of 0.59 . After $5 \mathrm{~min}$ of hand mixing, the fresh homogeneous geopolymers were poured into $50 \mathrm{~mm} \times 50 \mathrm{~mm} \times 50 \mathrm{~mm}$ plastic molds and placed on a vibration table for $2 \mathrm{~min}$ to remove entrapped air bubbles. The molds were then wrapped using a thin plastic sheet to prevent water evaporation and cured in a furnace at $60{ }^{\circ} \mathrm{C}$ for $24 \mathrm{~h}$. After curing, the molds were removed from the furnace and cooled at room temperature before demolding. The specimens were again sealed from ambient conditions and aged at targeted aging periods of 3,7 , and 28 days. 
Table 2. Mix proportioning of the geopolymer paste

\begin{tabular}{cccccc}
\hline Mix no. & $\mathbf{F A}(\mathbf{g})$ & Activator/FA & $\mathbf{N a}_{2} \mathbf{S i O}_{3} / \mathbf{N a O H}$ & $\mathbf{N a}_{2} \mathbf{S i O}_{3}(\mathbf{g})$ & $\mathbf{N a O H}(\mathbf{g})$ \\
\hline 1 & 450.00 & 0.59 & 0.5 & 88.00 & 177.00 \\
2 & & & 1.0 & 132.75 & 132.75 \\
3 & 450.00 & 0.59 & 1.5 & 153.90 & 102.60 \\
4 & 450.00 & 0.59 & 2.0 & 177.00 & 88.00 \\
5 & 450.00 & 0.59 & 2.5 & 189.64 & 75.85 \\
6 & 450.00 & 0.59 & 3.0 & 199.12 & 66.37 \\
\hline
\end{tabular}

\subsubsection{Preparation of FA Geopolymer Paste with Different Curing Regimes}

Mixture no. 2 (Table 2) was selected to prepare FA geopolymer paste specimens. The specimens were cured using different curing regimes to examine the effect of curing conditions on the strength development of FA geopolymer paste. In the first condition, geopolymer paste specimens $(50 \mathrm{~mm} \times 50 \mathrm{~mm} \times 50 \mathrm{~mm})$ were cured at different curing temperatures of $60^{\circ} \mathrm{C}, 70^{\circ} \mathrm{C}, 80^{\circ} \mathrm{C}$, and $90^{\circ} \mathrm{C}$ for a fixed curing period of $24 \mathrm{~h}$. In the second condition, geopolymer specimens $(50 \mathrm{~mm} \times 50 \mathrm{~mm} \times 50 \mathrm{~mm})$ were cured at $70^{\circ} \mathrm{C}$ for different curing times of $6,12,18,24$, and $30 \mathrm{~h}$. Under both curing conditions, the specimens were wrapped with a plastic sheet to prevent water evaporation during curing and aged for 3, 7, and 28 days.

\subsection{Compressive Strength Evaluation}

The compressive strength of $50 \mathrm{~mm} \times 50 \mathrm{~mm} \times 50 \mathrm{~mm}$ specimens was tested according to EN 12390-3 (2009). The compression test was performed using a speed rate of $50 \mathrm{~mm} / \mathrm{min}$ by using the Shimadzu Universal Testing Machine (Japan) with a maximum loading of $1,000 \mathrm{kN}$. A minimum of three specimens was tested to evaluate compressive strength.

\subsection{Scanning Electron Microscopy (SEM) Measurements}

The microstructures of the geopolymers were investigated through SEM using JSM-6460 LA Jeol (Japan). The specimen fragments were mounted in an epoxy resin, vacuumed, and coated with a thin platinum layer by using JFC-1600 auto-fine coater Jeol (Japan). The test was conducted using secondary electrons imaging (SEI). 3.

\section{Results and Discussion}

\subsection{Effect of $\mathrm{Na}_{2} \mathrm{SiO}_{3} / \mathrm{NaOH}$ Mass Ratio on the Strength Development of FA Geopolymers}

The FA geopolymers prepared with various $\mathrm{Na}_{2} \mathrm{SiO}_{3} / \mathrm{NaOH}$ mass ratios display dissimilar strength developments at 3, 7, and 28 days (Figure 3). The lowest $\mathrm{NaOH}$ content is detected from the samples with $\mathrm{Na}_{2} \mathrm{SiO}_{3} / \mathrm{NaOH}$ mass ratio of 3.0. This ratio produces the lowest strength development among the other ratios at all tested ages and thus presents the lowest geopolymerization reaction. While, at the highest $\mathrm{NaOH}$ solution from the samples with a $\mathrm{Na}_{2} \mathrm{SiO}_{3} / \mathrm{NaOH}$ mass ratio of 0.5 , the geopolymer exhibits relatively poor strength development at the tested ages. The strength development in the specimens with $\mathrm{Na}_{2} \mathrm{SiO}_{3} / \mathrm{NaOH}$ mass ratios of 0.5 and 3.0 implies the complexity of the geopolymerization reaction and the significance of the concentration of the alkaline activator constituents. 


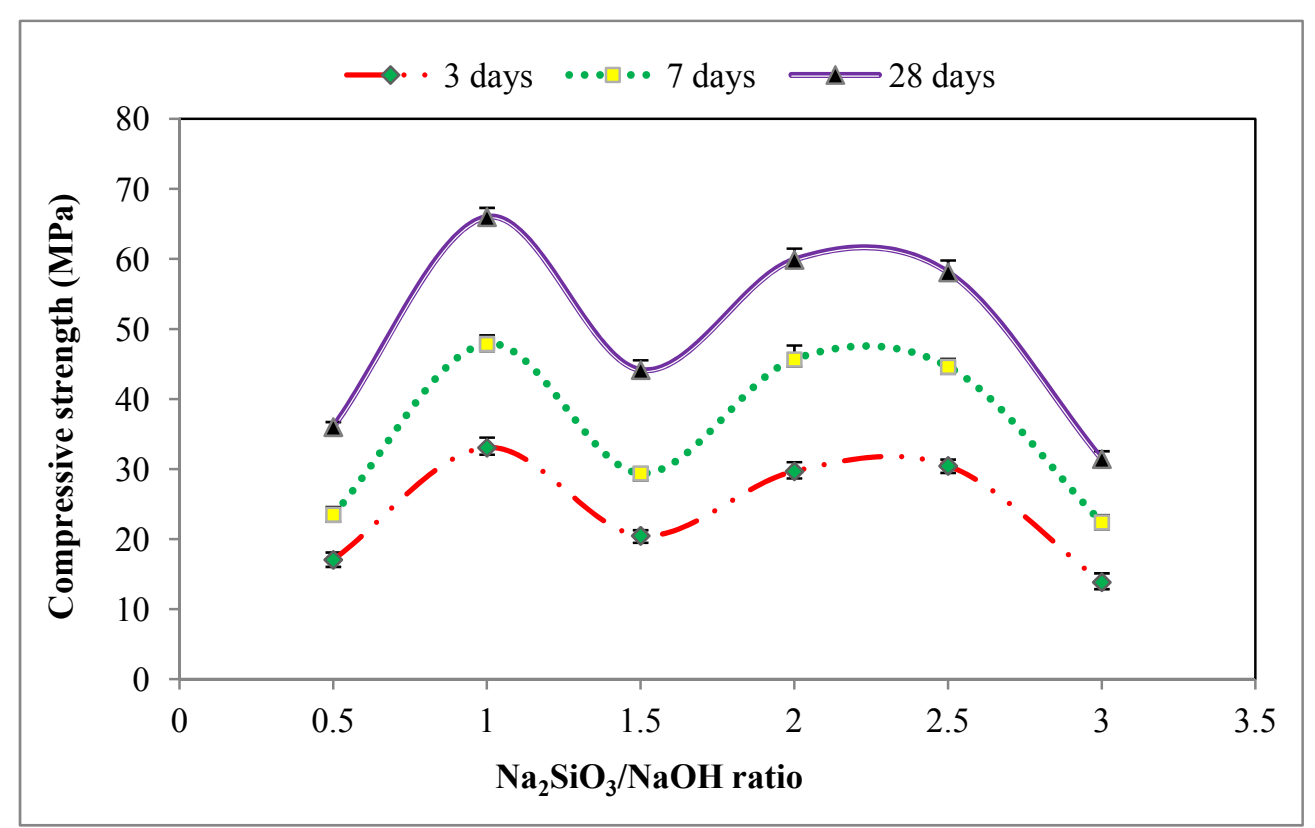

Figure 3. Effect of different $\mathrm{Na}_{2} \mathrm{SiO}_{3} / \mathrm{NaOH}$ mass ratios on the compressive strength development of the $\mathrm{FA}$ geopolymers paste

Furthermore, the specimen with a $\mathrm{Na}_{2} \mathrm{SiO}_{3} / \mathrm{NaOH}$ mass ratio of 1.0 exhibits the highest compressive strength at all ages and thus presents the highest geopolymerization reaction. Chindaprasirt, Chareerat \& Sirivivatnanon (2007) reported that the optimum $\mathrm{Na}_{2} \mathrm{SiO}_{3} / \mathrm{NaOH}$ mass ratio ranges from 0.67 to 1.0 produce $\mathrm{FA}$ (class $\mathrm{C}$ )-based geopolymers with optimal strength; this finding confirms the results shown in Figure 1. Although the specimen with $\mathrm{Na}_{2} \mathrm{SiO}_{3} / \mathrm{NaOH}$ mass ratio of 1.5 produces low strength development, the specimens prepared with $\mathrm{Na}_{2} \mathrm{SiO}_{3} / \mathrm{NaOH}$ mass ratios of 2 and 2.5 produce almost similar strength developments at all tested ages (Figure 3 ); such strengths were approximately parallel to the strengths obtained with the optimum $\mathrm{Na}_{2} \mathrm{SiO}_{3} / \mathrm{NaOH}$ ratio of 1.0 particularly at 3 and 7 days. The strength gaining behavior of the specimens with $\mathrm{Na}_{2} \mathrm{SiO}_{3} / \mathrm{NaOH}$ mass ratios of 2 and 2.5 is advantageous for large-scale production of FA geopolymer binders. Their significance is reflected in terms of economic efficiency because silicate-based activators are cheaper than hydroxide-based compounds.

Moreover, Figure 4 shows the SEM micrographs of the 28 days age FA geopolymers prepared with $\mathrm{Na}_{2} \mathrm{SiO}_{3} / \mathrm{NaOH}$ mass ratios of $0.5,1.00,2.00$ and 3.00. At the highest $\mathrm{NaOH}$ content of $\mathrm{Na}_{2} \mathrm{SiO}_{3} / \mathrm{NaOH}$ mass ratio of 0.5 of Figure 4a, the SEM micrograph indicates the high dissolution of the prime material (FA) by the absence of the unreacted FA microsphere similar to the microstructural characteristics of the geopolymer prepared with $\mathrm{Na}_{2} \mathrm{SiO}_{3} / \mathrm{NaOH}$ mass ratio of 1.0 of Figure $4 \mathrm{~b}$. However, the strength development for the $\mathrm{Na}_{2} \mathrm{SiO}_{3} / \mathrm{NaOH}$ mass ratio of 1.0 is significantly higher than that of 0.5 and this finding can be attributed to its higher $\mathrm{Na}_{2} \mathrm{SiO}_{3}$ content that entered into the reaction, considering that high content of silicate species may result in high strength development (Palomo, Grutzeck \& Blanco, 1999).

Figure 4c shows the SEM micrograph of the geopolymer prepared with $\mathrm{Na}_{2} \mathrm{SiO}_{3} / \mathrm{NaOH}$ mass ratio of 2.0 indicating the appearance of unreacted FA microsphere portion in the microstructure. The SEM micrographs of Figure 4d shows the high content of unreacted FA microspheres in the microstructure of the FA geopolymer prepared with $\mathrm{Na}_{2} \mathrm{SiO}_{3} / \mathrm{NaOH}$ mass ratio of 3.0. This result is significantly related to the low dissolution rates of $\mathrm{Si}$ and $\mathrm{Al}$ species of FA that entered into the reaction caused by the insufficient alkalinity of the alkaline activator prepared at this mixing ratio. The insufficient alkalinity of $\mathrm{Na}_{2} \mathrm{SiO}_{3} / \mathrm{NaOH}$ mass ratio of 3.0 resulted in the lowest strength development than other ratios as illustrated in Figure 3. 

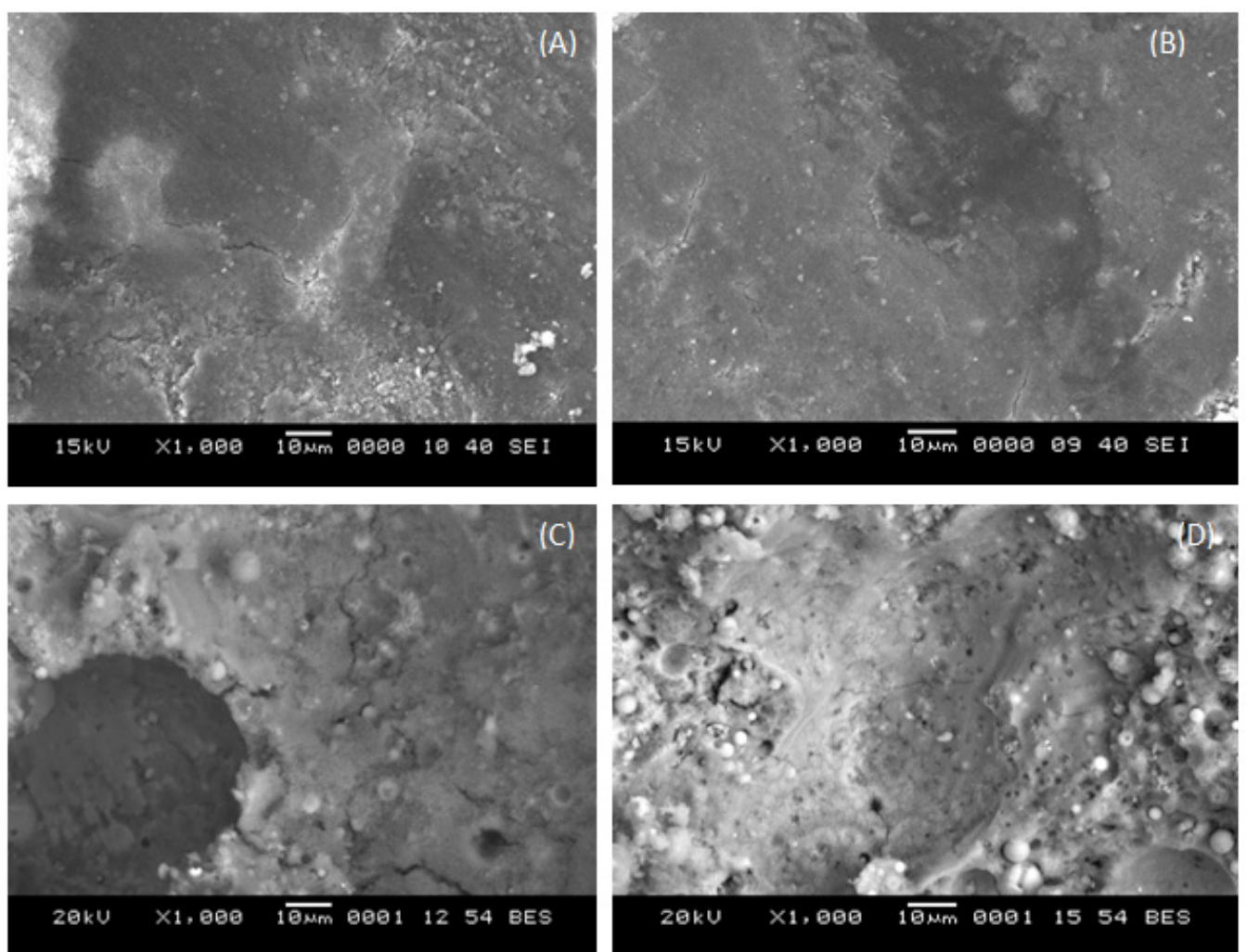

Figure 4. SEM micrographs of the FA-based geopolymers prepared at different $\mathrm{Na}_{2} \mathrm{SiO}_{3} / \mathrm{NaOH}$ mass ratios at age of 28 days (A) 0.5, (B) 1.0, (C) 2.0, (D) 3.0.

\subsection{Effect of Curing Temperature on the Strength Development of FA Geopolymers}

The mechanism of the geopolymerization reaction is based on the fast dissolution and polycondensation of $\mathrm{Si}$ and $\mathrm{Al}$ oxides of $\mathrm{FA}$ in the presence of sufficient $\mathrm{Na}^{+}$and $\mathrm{OH}^{-}$species of the alkaline activator to form a three-dimensional polymeric Si-O-Al-O gel (Ryu et al., 2013). The hardening of the geopolymeric material is attributed to water liberation from the fresh aluminosilicate gel structure. Therefore, curing the fresh geopolymers at temperatures higher than the ambient is preferred to accelerate the geopolymerization reaction and decrease the setting time (Bakharev, 2005). Figure 5 shows the compressive strength development of the FA geopolymers pastes cured at different temperatures ranging from $60{ }^{\circ} \mathrm{C}$ to $90{ }^{\circ} \mathrm{C}$ with $10{ }^{\circ} \mathrm{C}$ increment at aging periods of 3,7 , and 28 days. Although the highest compressive strength at all tested ages is detected at $70^{\circ} \mathrm{C}$, the varied curing temperatures produce comparable compressive strengths at 3 and 7 days. The specimens cured at $80{ }^{\circ} \mathrm{C}$ and $90{ }^{\circ} \mathrm{C}$ and aged for 28 days show relatively lower strength development than geopolymers cured at $70{ }^{\circ} \mathrm{C}$. The loss of moisture at curing temperatures of $80{ }^{\circ} \mathrm{C}$ and $90{ }^{\circ} \mathrm{C}$ may cause the reduction in strength because the geopolymerization reaction requires the presence of moisture to develop good strength (Chindaprasirt, Chareerat \& Sirivivatnanon 2007). 


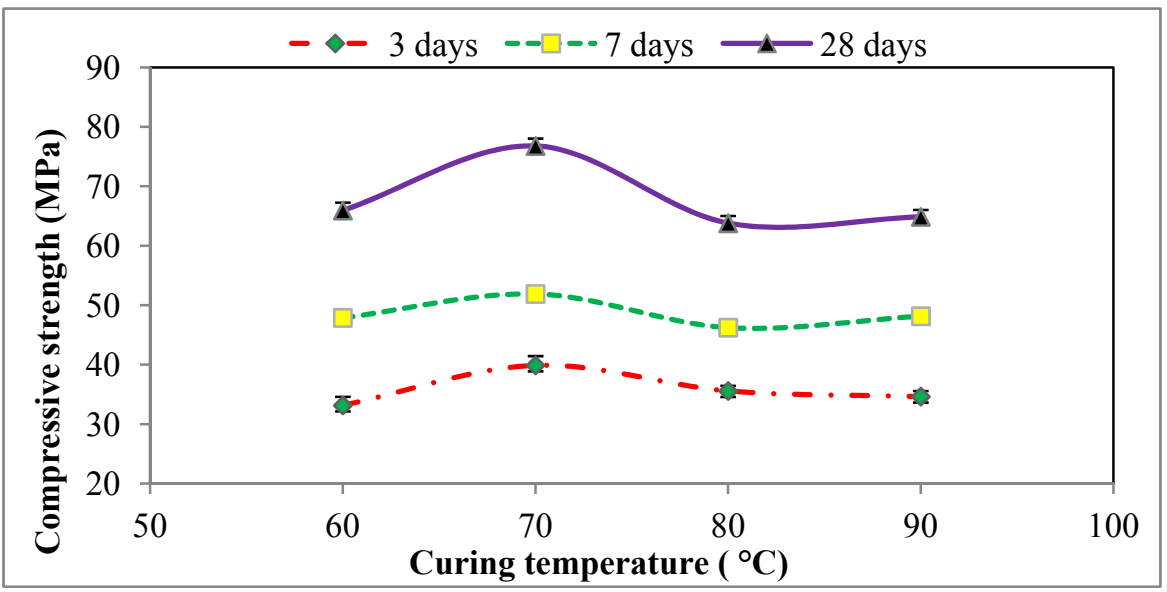

Figure 5. Effect of different curing temperatures on the compressive strength development of the FA geopolymers paste

\subsection{Effect of Curing Period on the Strength Development of FA Geopolymers}

Figure 6 presents the effect of curing periods from $6 \mathrm{~h}$ to $30 \mathrm{~h}$ with increment of $6 \mathrm{~h}$ on the compressive strength development of the FA geopolymer paste specimens. The strength development of the resultant geopolymers increases with increasing curing period up to $24 \mathrm{~h}$. The specimen cured for $24 \mathrm{~h}$ exhibits the optimum compressive strength at all testing ages compared with those cured for 6,12 , and $18 \mathrm{~h}$. This finding demonstrates that the highest geopolymerization reaction rate can be obtained at long curing time. However, curing FA geopolymers for more than $24 \mathrm{~h}$ up to $30 \mathrm{~h}$ negatively affects the strength development. The prolonged curing of more than $24 \mathrm{~h}$ may result in the breakdown of the gel structure of the geopolymer matrix, leading to low resultant strength (van Jaarsveld, van Deventer \& Lukey, 2002).

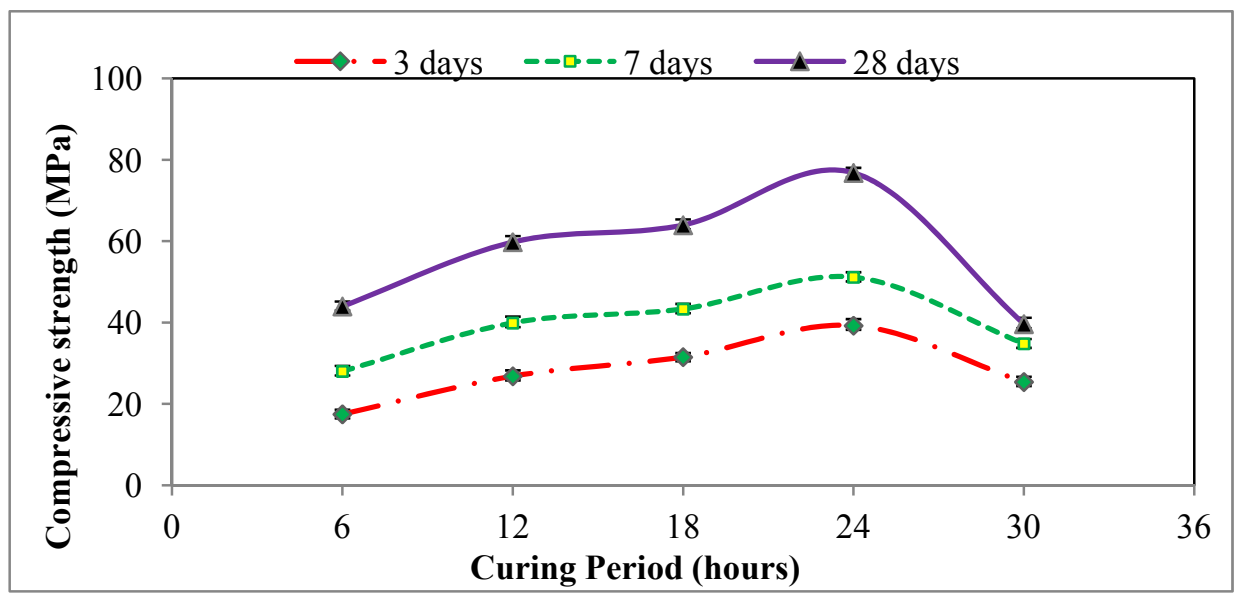

Figure 6. Strength development of the geopolymers paste at different curing periods

\section{Conclusions}

The following conclusions are established in this paper:

- The mixing ratio of $\mathrm{Na}_{2} \mathrm{SiO}_{3} / \mathrm{NaOH}$ affected the development of high-strength FA geopolymers. With sufficient alkaline contents and $\mathrm{Si}$ species available in the geopolymerization reaction, the strength development of the hardened geopolymer continued to increase with aging time. Although the $\mathrm{Na}_{2} \mathrm{SiO}_{3} / \mathrm{NaOH}$ ratio of 1.00 showed the highest strength development, $\mathrm{Na}_{2} \mathrm{SiO}_{3} / \mathrm{NaOH}$ ratios of 2 and 2.5 were apparently more applicable for large-scale production of FA geopolymer binders in terms of economic aspects.

- $\quad$ SEM results showed the effect of $\mathrm{NaOH}$ solution content on the dissolution of the prime materials (FA). The higher content of $\mathrm{NaOH}$ solution the higher dissolution of FA. However, with low content of $\mathrm{Na}_{2} \mathrm{SiO}_{3}$ in the alkaline activator as the $\mathrm{Na}_{2} \mathrm{SiO}_{3} / \mathrm{NaOH}$ ratios of 0.5 resulted in relatively low strength development 
at different ages.

- The optimum curing temperature for FA geopolymers was $70{ }^{\circ} \mathrm{C}$, and curing temperatures of $80{ }^{\circ} \mathrm{C}$ and $90{ }^{\circ} \mathrm{C}$ adversely affected the strength development after aging for 28 days. This finding presented another advantage in terms of decreasing the cost of curing process.

- Long curing periods produced high-strength geopolymers. However, extending the curing period for more than $24 \mathrm{~h}$ negatively affected the strength development at different testing ages.

\section{References}

Abdulkareem, O. A., Abdullah, M. M. A, Kamaruddin, H., Isamail, K., \& Ala'ddin A. Saif. (2014). Effects of Elevated Temperatures on the Thermal Behavior and Mechanical Performance of Fly Ash Geopolymer Paste, Mortar and Lightweight Concrete. Construction and Building Materials, 50, 377-387. http://dx.doi.org/10.1016/j.conbuildmat.2013.09.047

Abdulkareem, O. A., Abdullah, M. M. A, Kamaruddin, H., Isamail, K., \& Binhussain, M. (2013). Mechanical and microstructural evaluations of lightweight aggregate geopolymer concrete before and after exposed to elevated temperatures. Materials, 6(10), 4450-4461. http://dx.doi.org/10.3390/ma6104450

Álvarez-Ayuso, E., Querol, X., Plana, F., Alastuey, A., Moreno, N., \& Izquierdo, M. et al. (2008). Environmental, physical and structural characterisation of geopolymer matrixes synthesised from coal co-combustion fly ashes. Journal of Hazardous Materials, 154(1), 175-183. http://dx.doi.org/10.1016/j.jhazmat.2007.10.008

American Standard of Testing Materials (ASTM) C618-08a. Standard specification for coal fly ash and raw or calcined natural pozzolan for use in concrete. ASTM international; 2008.

Bakharev, T. (2005). Geopolymeric materials prepared using Class F fly ash and elevated temperature curing. Cement and Concrete Research, 35(6), 1224-1232. http://dx.doi.org/10.1016/j.cemconres.2004.06.031

Chindaprasirt, P., Chareerat, T., \& Sirivivatnanon, V. (2007). Workability and strength of coarse high calcium fly ash geopolymer. Cement and Concrete Composites, 29(3), 224-229. http://dx.doi.org/10.1016/j.cemconcomp.2006.11.002

Davidovits J. (1999). Chemistry of geopolymeric systems, terminology. Proceedings of Second International Conference on Geopolymers, Saint- Quentin, France, 9-40.

Detphan S., \& Chindaprasirt P. (2009). Preparation of fly ash and rice husk ash geopolymer. International $\begin{array}{llll}\text { Journal of Minerals, Metallurgy and } & \text { Materials, 16, 720-726. }\end{array}$ http://dx.doi.org/10.1016/S1674-4799(10)60019-2

Duxson, P., Fernandez-Jimenez, A., Provis, J. L., Lukey, G. C., Palomo, A., \& van Deventer, J. S. J. (2007). Geopolymer technology: the current state of the art. Journal of Material Science, 42, 17-2933. http://dx.doi.org/10.1007/s10853-006-0637-z.

Duxson, P., Provis, J. L., Lukey, G. C., Mallicoat, S. W., Kriven, W. M., \& Van Deventer, J. S. (2005). Understanding the relationship between geopolymer composition, microstructure and mechanical properties. Colloids and Surfaces A: Physicochemical and Engineering Aspects, 269(1), 47-58. http://dx.doi.org/10.1016/j.colsurfa.2005.06.060

European Standard, CEN/TC 104. EN 12390-3, Testing hardened concrete-part 3: compressive strength of testing specimens. Brussels; 2009.

Fernandez-Jimenez, A. M., Palomo, A., \& Lopez-Hombrados, C. (2006). Engineering properties of alkali-activated fly ash concrete. ACI Materials Journal, 103(2), 106-112. http://dx.doi.org/10.14359/15261

Fernández-Jiménez, A., Garcia-Lodeiro, I., \& Palomo, A. (2007). Durability of alkali-activated fly ash cementitious materials. Journal of Materials Science, 42(9), 3055-3065. http://dx.doi.org/10.1007/s10853-006-0584-8

Glukhovsky, V. (1981). Slag-alkali concretes produced from fine-grained aggregate. Kiev: Vishcha Shkolay. USSR (1981) in Russian.

Gourley, J., \& Johnson, G. (2005). Developments in geopolymer precast concrete. In: Proceeding of fourth World Congress geopolymer, Geopolymer Institute, France, 133-137.

Hardjito, D., \& Rangan, B. V. (2005). Development and properties of Low-Calcium fly ash-based geopolymer concrete. Research report GC1, Curtin University of Technology, Australia.

Kong, D. L. Y., \& Sanjayan, J. G. (2008). Damage behavior of geopolymer composites exposed to elevated 
temperatures. Cement and Concrete Composite, $\quad 30, \quad$ 986-991. http://dx.doi.org/10.1016/j.cemconcomp.2008.08.001

Kong, D. L. Y., \& Sanjayan, J. G. (2010). Effect of elevated temperatures on geopolymer paste, mortar and concrete. Cement and Concrete Research, 40, 334-339. http://dx.doi.org/10.1016/j.cemconres.2009.10.017

Kovalchuk, G., Fernández-Jiménez, A., \& Palomo, A. (2007). Alkali-activated fly ash: Effect of thermal curing conditions on mechanical and microstructural development-Part II. Fuel, 86(3), 315-322. http://dx.doi.org/10.1016/j.fuel.2006.07.010

Li, Z., Ding, Z., \& Zhang, Y. (2004). Development of sustainable cementitious materials in: International Workshop on Sustainable Development and Concrete Technology, edited by K. Wang, Beijing, China, May 20-21.

Nazari, A., Riahi, S., \& Bagheri, A. (2012). Designing water resistant lightweight geopolymers produced from waste materials. Materials and Design, 35, 296-302. http://dx.doi.org/10.1016/j.matdes.2011.09.016

Nematollahi, B., \& Sanjayan, J. (2014). Effect of different superplasticizers and activator combinations on workability and strength of fly ash based geopolymer. Materials and Design, 57, 667-672. http://dx.doi.org/10.1016/j.matdes.2014.01.064

Palomo, A., Grutzeck, M., \& Blanco, M. (1999). Alkali-activated fly ashes: A cement for the future. Cement and Concrete Research, 29(8), 1323-1329. http://dx.doi.org/10.1016/S0008-8846(98)00243-9

Rashad, A. M. (2014). A comprehensive overview about the influence of different admixtures and additives on the properties of alkali-activated fly ash. Materials and Design, 35, 1005-1025. http://dx.doi.org/10.1016/j.matdes.2013.07.074

Rukzon, S., Chindaprasirt, P., \& Mahachai, R. (2009). Effect of grinding on chemical and physical properties of rice husk ash. International Journal of Minerals, Metallurgy and Materials, 16(2), 242-247. http://dx.doi.org/10.1016/S1674-4799(09)60041-8

Ryu, G. S., Lee, Y. B., Koh, K. T., \& Chung, Y. S. (2013). The mechanical properties of fly ash-based geopolymer concrete with alkaline activators. Construction and Building Materials, 47, 409-418. http://dx.doi.org/10.1016/j.conbuildmat.2013.05.069.

Song, X., Marosszeky, M., Brungs, M., \& Munn, R. (2005). Durability of fly ash based geopolymer concrete against sulphuric acid attack. Proceedings From: The $10^{\text {th }}$ DBMC, International Conference on Durability of Building Materials and Components, Lyon, France. 123-129.

Temuujin, J., van Riessen, A., \& MacKenzie, K. J. D. (2010). Preparation and characterisation of fly ash based geopolymer mortars. Construction and Building Materials, 40, $1906-1910$. http://dx.doi.org/10.1016/j.conbuildmat.2010.04.012

Thakur, R. N., \& Ghosh, S. (2006). Effect of mix composition on compressive strength and microstructure of fly ash based geopolymer composites. ARPN Journal of Engineering and Applied Sciences, 4(4), 68-74.

van Jaarsveld, J., van Deventer, J., \& Lukey, G. (2002). The effect of composition and temperature on the properties of fly ash-and kaolinite-based geopolymers. Journal of Chemical Engineering, 89(1), 63-73.

Wallah, S., \& Rangan, B. (2006). Low- calcium fly ash based geopolymer concrete: Long-term properties. Research Report GC 2, Curtin University of Technology, Perth, Australia, 97.

Wallah, S., Hardjito, D., Sumajouw, D., \& Rangan, B. (2005). Creep and Drying Shrinkage Behaviour of Fly Ash-Based Geopolymer Concrete. proceedings from: The 22nd Biennial Conference Concrete. New South Wales, Australia, 153-159.

Xu, H., \& Van Deventer, J. (2000). The geopolymerisation of alumino-silicate minerals. International Journal of Mineral Processing, 59(3), 247-266. http://dx.doi.org/10.1016/S0301-7516(99)00074-5

\section{Copyrights}

Copyright for this article is retained by the author(s), with first publication rights granted to the journal.

This is an open-access article distributed under the terms and conditions of the Creative Commons Attribution license (http://creativecommons.org/licenses/by/3.0/). 